\title{
Evidence for Epigenetic Changes in the Estrogen Receptor Alpha Promoter in Lymphangioleiomyomatosis (LAM)
}

\author{
Daniel J. Noonan* and Dingyuan Lou
}

Department of Molecular and Cellular Biochemistry, University of Kentucky, 741 South Limestone Street, Lexington, KY 40536, USA

\begin{abstract}
Lymphangioleiomyomatosis (LAM) is a rare but often fatal disease, characterized by the abnormal proliferation of smooth muscle cells of the lung. LAM occurs almost exclusively in women and its pathology correlates with mutations in the tuberous sclerosis complex 2 (TSC2) gene and expression of the hormone estrogen. One of the hallmarks of LAM lesions is the anomalous expression of the intracellular receptor for estrogens, ER $\alpha$, and the distinct gender specificity of LAM would support the hypothesis that this anomalous expression of ER $\alpha$ plays an essential role in the pathology of the disease. Our previous studies have defined a direct link between the TSC2 gene product tuberin and estrogen signaling through ER $\alpha$. The objectives of this study were to investigate epigenetic changes in the ER $\alpha$ promoter as a mechanism for upregulation of ER $\alpha$ expression in LAM disease. The results of this study provide evidence for: a) use of multiple ER $\alpha$ promoters in human airway smooth muscle cells and LAM- associated cell lines, $b$ ) epigenetic changes in the promoter of the ER $\alpha$ gene in LAM-associated cell lines and LAM lesions, and c) differential binding of histone deacetylase 1 and methyl-CpG binding proteins in human airway smooth muscle and LAM cells. These studies cumulatively suggest the upregulation of ER $\alpha$ expression associated with LAM disease may in part be a consequence of demethylation at the $\mathrm{ER} \alpha$ promoter.
\end{abstract}

Keywords: Tuberous sclerosis, tuberin, methylation, TSC2.

\section{INTRODUCTION}

Lymphangioleiomyomatosis (LAM) is a rare disease occurring almost exclusively in women and characterized by proliferation of smooth muscle cells of the lung [1-3]. The most common presenting symptoms are dyspnea and pneumothorax. Although LAM lesions are composed of multiple cell populations, the predominant proliferating cell found in LAM lesions appears to be the myofibroblast-like spindle-shaped cells that express immunoreactivity to a variety of smooth muscle cell markers $[4,5]$. Uncharacteristic of smooth muscle cells of the lung, these cells also express the cell surface protein gp100 (HMB-45 positive) and intracellular receptors for the hormones estrogen (ER $\alpha)$ and progesterone (PR) [6, 7]. It is these latter 2 that have been hypothesized to play an integral role in the gender specificity of LAM.

LAM pathogenesis has been shown to correlate with both expression of the hormone estrogen [8-10] and mutations in the TSC2 gene [11, 12]. Although exceptions have been identified [13-18], the vast majority of LAM patients fall into the category of post-pubescent but pre-menopausal women. This observation would strongly suggest estrogen hormone signaling plays a role in LAM pathogenesis, and is further supported by published observations that pregnancy in women with LAM seems to exacerbate the disease while anti-estrogen therapies including oophorectomy [19], ovarian

*Address correspondence to this author at the Department of Molecular and Cellular Biochemistry, University of Kentucky, 741 South Limestone Ave., Lexington, KY 40536, USA; Tel: (859) 257-7498; Fax: (859) 323-1037;

E-mail: dnoonan@uky.edu irradiation [20] and progesterone administration [9, 21] appear to lessen the severity of the disease.

LAM occurs either as an isolated disorder (sporadic LAM) or in association with tuberous sclerosis complex TSC (TSC-LAM). TSC is an autosomal dominant neurocutaneous disease that leads to the development of hamartomatous lesions in a variety of tissue types including brain, kidney, heart, skin, eye and lung [22]. TSC has been genetically mapped in humans to two distinct loci, TSC1 and TSC2 [23], and both sporadic LAM and TSC-LAM have been linked to mutations in the TSC genes [12]. The TSC1 gene encodes hamartin, a 130 kilodalton protein containing 1164 amino acids [24]. The TSC2 gene encodes a 198 kilodalton protein called tuberin, containing 1807 amino acids [25]. Together these proteins have been identified in complexes regulating cell growth, cell adhesion, cell migration and a variety of intracellular signaling pathways (reviewed in: [26, 27]). Tuberin and hamartin also appear to maintain distinct cellular locations $[28,29]$ and distinct cellular functions that include regulation of nuclear receptor gene activities [30], cell motility [31-33], cytokinesis [34] and cell growth [3538].

Previous studies from our laboratory and that of others have demonstrated that tuberin can directly impact ER $\alpha$ mediated genomic and nongenomic signaling [39-42]. Cumulatively these data support the hypothesis that, if ER $\alpha$ is present in a cell, disruption of tuberin/hamartin-associated signaling events can directly impact signaling pathways mediated by ER $\alpha$. Consistent with this hypothesis is the corollary that LAM gender specificity and pathogenesis is linked to the up-regulation of ER $\alpha$ expression in tuberin/ 
hamartin disrupted lung smooth muscle cells. The objective of this study was to investigate a potential mechanism that could serve as either a cause or exacerbation of ER $\alpha$ anomalous expression in lung smooth muscle cells. Evidence is presented for epigenetic changes, in the form of $\mathrm{CpG}$ demethylation, occurring at the promoter region of the ER $\alpha$ gene in LAM-associated cell lines and LAM lesions. These changes are further shown to correlate with reduced association of this promoter with the transcription repressor histone deacetylase 1 (HDAC1) and a methyl-CpG binding protein. Cumulatively these data support the hypothesis that the ER $\alpha$ promoter in LAM lesions is subject to epigenetic changes that facilitate an upregulation of ER $\alpha$ gene expression.

\section{MATERIALS AND METHODOLOGY}

\section{Cell Lines and Lung Tissues}

The LAM cell line and control human airway smooth muscle (HASM) cells used in these studies were as previously described [43] and a generous gift from Drs. Vera Krymskaya and Ray Panettieri (University of Pennsylvania, Philadelphia, PA). The LAM cell line was established from a LAM lung lesion and previously characterized as having mutations in both TSC2 alleles and expressing ER $\alpha$. These cells were used in low passage (between 5 through 10). The second LAM-associated TSC2 defective cell line employed in these studies (AML-101) was a generous gift from Rachel Squillace at the Rothberg Institute (Guilford, CT). The AML-101 cell line is a transformed version of the LAMassociated AML-621 estrogen responsive human angiomyolipoma-derived cell line described by $\mathrm{Yu}$ et al. [44]. The human embryonic kidney-293 (HEK-293) and human breast cancer-derived MCF-7 cell lines were purchased from ATCC (Manassas, VA).

The 5 LAM lung tissue specimen used in these studies were obtained from the NIH repository of LAM patient diseased lung tissues and/or DNA preparations. These tissues were obtained under an IRB protocol (\#04-0715-P3G) approved by the University of Kentucky Institutional Review Board. The tissues in the NIH LAM repository are derived exclusively from women (between 21 and 65 years) and of all ethnic groups. These women suffer from end-stage LAM disease and as a result undergo lung transplantation. The tissues were snap frozen lung specimen that were defined by pathology as being derived from LAM lesions or normal lung. The tissue samples were provided with number identifiers only and those identifiers have been redesignated as L1-L5 for these studies.

The 2 female human normal lung samples used in these studies were specimen obtained under IRB approval (\#000556-P3R) from the Pathology Department at the University of Kentucky. These samples were provided as snap frozen tissues with number identifiers. The identifiers have been simplified to the N1 and N2 designations used here. The rarity of this disease and the limited availability of tissues did not permit age matching of tissues for the LAM specimen and normal controls.

\section{ER $\alpha$ Promoter-Driven Luciferase Constructs}

Using overlapping oligonucleotides, the $70 \mathrm{bp}$ ER $\alpha$ 5'UTR sequence shared by all ER $\alpha$ promoters $[45,46]$ was initially subcloned upstream of a firefly luciferase gene in the pGL3-Basic vector (Promega, Madison, WI, USA). This construct served as the mother vector for subcloning the $\mathrm{ER} \alpha-\mathrm{A}, \mathrm{B}, \mathrm{C}, \mathrm{E}$ and $\mathrm{F}$ promoters. These promoter fragments were isolated from human genomic DNA using oligonucleotides (see Table 1) that permitted fusion of the respective promoters into a unique Mlu I restriction site upstream of the common $70 \mathrm{bp}$ ER $\alpha$ 5'-UTR sequence. The sequence integrity of all constructs was validated by DNA sequencing.

\section{ER $\alpha$ Promoter-Specific RT-PCR Analyses}

RNA was isolated from cells and tissues using Trizol reagent (Sigma, St. Louis, MO, USA) according to manufacturer's protocols. To characterize ER $\alpha$ promoter usage in LAM and MCF-7 cells, standard RT-PCR analyses utilizing ER $\alpha-\mathrm{A}, \mathrm{B}, \mathrm{C}, \mathrm{D}, \mathrm{E}$ and $\mathrm{F}$ specific nested PCR primers, along with a common ER $\alpha$ exon 2 primer were used as previously described [46]. Briefly, tandem pairs of forward primers specific for each ER $\alpha$ promoter (A-F) along with a common tandem pair of reverse primers for ER $\alpha$ exon 2 were used in sequential nested PCR reactions. Primers and reaction conditions were exactly as previously described [46]. Parallel GAPDH RT-PCR analyses (see table for specific primers) were performed for normalizing data. PCR products were separated on $2 \%$ agarose gels and identified by ethidium bromide staining.

\section{Western Blot Analyses}

Protein from tissues and cell lines was isolated and analyzed for ER $\alpha$ expression in Western blot analyses as we have previously described [47]. The antibody (AB-15) used for $\mathrm{ER} \alpha$ detection was purchased from Lab Vision Corporation (Fremont, CA, USA).

\section{Methylation Analyses}

Sodium bisulfite modifications of DNA were performed using a commercially available kit (EZ DNA Methylation Kit, Zymo Research, Orange, CA, USA) according to manufacturers instructions. Briefly, 1 ug of DNA was incubated at $37^{\circ} \mathrm{C}$ for $15 \mathrm{~min}$ in $1 \mathrm{x} \mathrm{M}$-dilution buffer. To this was added 2-fold excess CT Conversion Reagent. This was incubated $12 \mathrm{hr}$ at $50^{\circ} \mathrm{C}$. Following the $12 \mathrm{hr}$ incubation samples were mixed with an equal volume of M-Binding Buffer and loaded onto a Zymo-Spin I Column. Columns were centrifuged briefly at $12,000 \mathrm{~g}$, washed with $200 \mathrm{ul}$ of M-Wash Buffer, 200 ul of M-Desulphonation Buffer, $200 \mathrm{ul}$ of M-Wash Buffer and eluted with 10 ul of M-Elution Buffer.

For direct characterization of methylated DNA sequences, PCR primers were designed (see Table 1) to non$\mathrm{CpG}$ containing sequences that surround the ER $\alpha-\mathrm{A}$ promoter sequence. These were used in cycle sequencing reactions with bisulfite modified DNAs from the various cell lines as described in the relevant figure legends. A commercially available cycle sequencing kit (Amersham Biosciences, Pittsburg, PA, USA) was used according to the manufacturers detailed instructions. For analyzing the relative demethylation at the various $\mathrm{GpG}$ in our sequencing autoradiographs, a Kodak Imaging 3.5 System and its associated 1D Image Analysis Software was used. Bands were normalized to background and an average pixel density 
Table 1. Various Oligonucleotide Primers Used in Plasmid Constructions, RT-PCR Analyses and CpG Methylation Sequencing

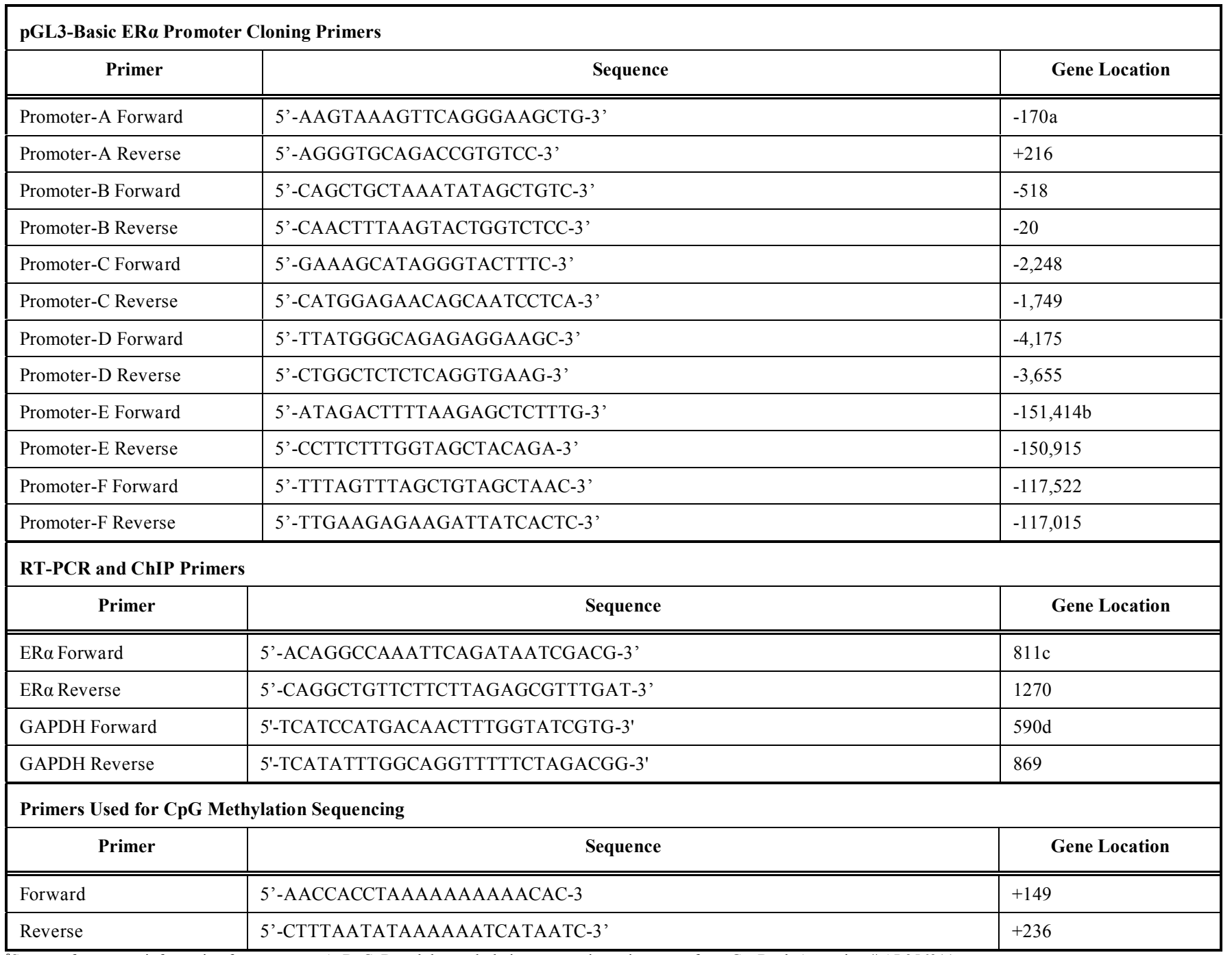

${ }^{\mathrm{a}}$ Source of sequence information for promoters A, B, C, D and the methylation sequencing primers are from GenBank Accession \# AL356311.

${ }^{\mathrm{b}}$ Source of sequence information for promoters E and F are derived from GenBank Accession \# AB090237.

${ }^{\mathrm{c}}$ Source of sequence information for ER $\alpha$ PCR primers is from GenBank Accession \#NM000125.

${ }^{\mathrm{d}}$ Source of sequence information for GAPDH PCR primers is from GenBank Accession \#NM002046.

value for a set region of interest (band) was established. Bands with pixel density values within $40 \%$ of this value were categorized as $(+)$, bands with pixel density values $10 \%$ or less of this value were categorized as (-), bands with pixel density values $11-60 \%$ below this average were classified weak and bands with pixel density values greater than $140 \%$ of this average were classified as strong.

\section{ChIP Assays}

Modified chromatin immunoprecipitation (ChIP) assays were performed essentially as previously described [48]. Briefly, LAM and HASM cells, treated and untreated with $2 \mathrm{uM} 5$-azadeoxycytidine for $96 \mathrm{~h}$, were incubated $10 \mathrm{~min}$ in $1 \%$ formaldehyde, brought to $0.125 \mathrm{M}$ glycine and incubated another $5 \mathrm{~min}$. The cells were lysed by Dounce homogenization in lysis buffer (5mM PIPES, $85 \mathrm{mM} \mathrm{KCl}$, $0.5 \%$ Nonidet P-40 and protease inhibitors) and nuclei were isolated by centrifugation. Nuclei were lysed in nuclei lysis buffer $(50 \mathrm{mM}$ Tris, $10 \mathrm{mM}$ EDTA, $1 \%$ SDS and protease inhibitors) and chromatin was sheered by sonication. Sonicated lysates were diluted with 2 volumes of IP dilution buffer $(0.01 \%$ SDS, $1.1 \%$ Triton X-100, 1.2mM EDTA, $16.7 \mathrm{mM}$ Tris- $\mathrm{HCl}, 167 \mathrm{mM} \mathrm{NaCl}$ and protease inhibitors) and incubated overnight with a rabbit polyclonal antiMeCpG2 (Imgenex, San Diego, CA, USA: IMG-297) antibody or a rabbit polyclonal HDAC1 (Imgenex, San Diego, CA, USA: IMG-337) antibody. Staphylococcus aureus (Staph A: Pansorbin, Calbiochem, San Diego, CA, USA) cells were added, incubated $15 \mathrm{~min}$, centrifuged and the pellet was washed with IP dilution buffer. Protein complexes were eluted by the addition of elution buffer (50mM NaHCO3, 1\% SDS). Elutions were brought to $0.3 \mathrm{M}$ $\mathrm{NaCl}$ and incubated at $65^{\circ} \mathrm{C}$ for $5 \mathrm{hr}$ to reverse the crosslinking. DNA was purified by standard phenol/chloroform/isoamyl alcohol extraction and ethanol precipitation. This DNA sample was analyzed by PCR analyses for the presence of ER $\alpha$ promoter-A DNA (see Table 1 for primers used). 


\section{Demethylation Analyses}

The impact demethylation has on ER $\alpha$ mRNA expression was analyzed as previously described [49]. Briefly, LAM and HASM cells were plated at $50 \%$ confluency in $10 \mathrm{~cm}$ dishes. Cells were treated with 2uM 5-azadeoxycytidine (5azadC: Sigma, St. Louis, MO) for 96 hours, changing the media every 24 hours. Twenty-four hours prior to harvesting, the cells were treated with $5 \mathrm{mM}$ 4-phenylbutyrate (4-PBA: Calbiochem, San Diego, CA, USA). RNA was isolated from cells and cDNA was synthesized from 5ug of total RNA from treated and untreated LAM and HASM cells using a commercially available First Strand cDNA Synthesis Kit (Fermentas, Amherst, NY). This cDNA was analyzed for ER $\alpha$ mRNA expression using a SYBR Green Real-Time PCR Kit (Stratagene, San Diego, CA, USA) and an Mx4000 Real-Time PCR machine (Stratagene). PCR primers for these studies can be found in Table $\mathbf{1}$.

\section{Statistical Analyses}

Statistical differences between experimental groups were determined by ANOVA and Tukey's multiple comparison analysis. Data are expressed as means \pm SEM for 3 independent experiments. $\mathrm{P}$ values equal to or less than 0.05 were considered significant.

\section{RESULTS}

\section{LAM-Associated Cell Lines Express ER $\alpha$ mRNA via Multiple ER $\alpha$ Promoters}

The 5' regulatory region for the ER $\alpha$ gene is a complex structure consisting of up to 7 different promoters, designated $\mathrm{A}$ to $\mathrm{F}$ and $\mathrm{T}$ (reviewed in: [45]), that span $>150$ $\mathrm{kb}$ of DNA. The predominant promoters utilized for expression of the ER $\alpha$ gene in most cells and tissues are the $\mathrm{A}$ and $\mathrm{B}$ promoters, although there have been some reported novel cancer and tissue-specific switching of promoter utilization. To identify which of the ER $\alpha$ promoters are used in LAM, total RNA was isolated from a LAM cell line and an AML immortalized cell line [43]. A set of nested primers that distinguish the various ER $\alpha$ promoters, together with a common ER $\alpha$ exon 2 primer, were designed as previously described [50] and used in RT-PCR analyses of the respective RNAs (Fig. 1). As positive and negative controls
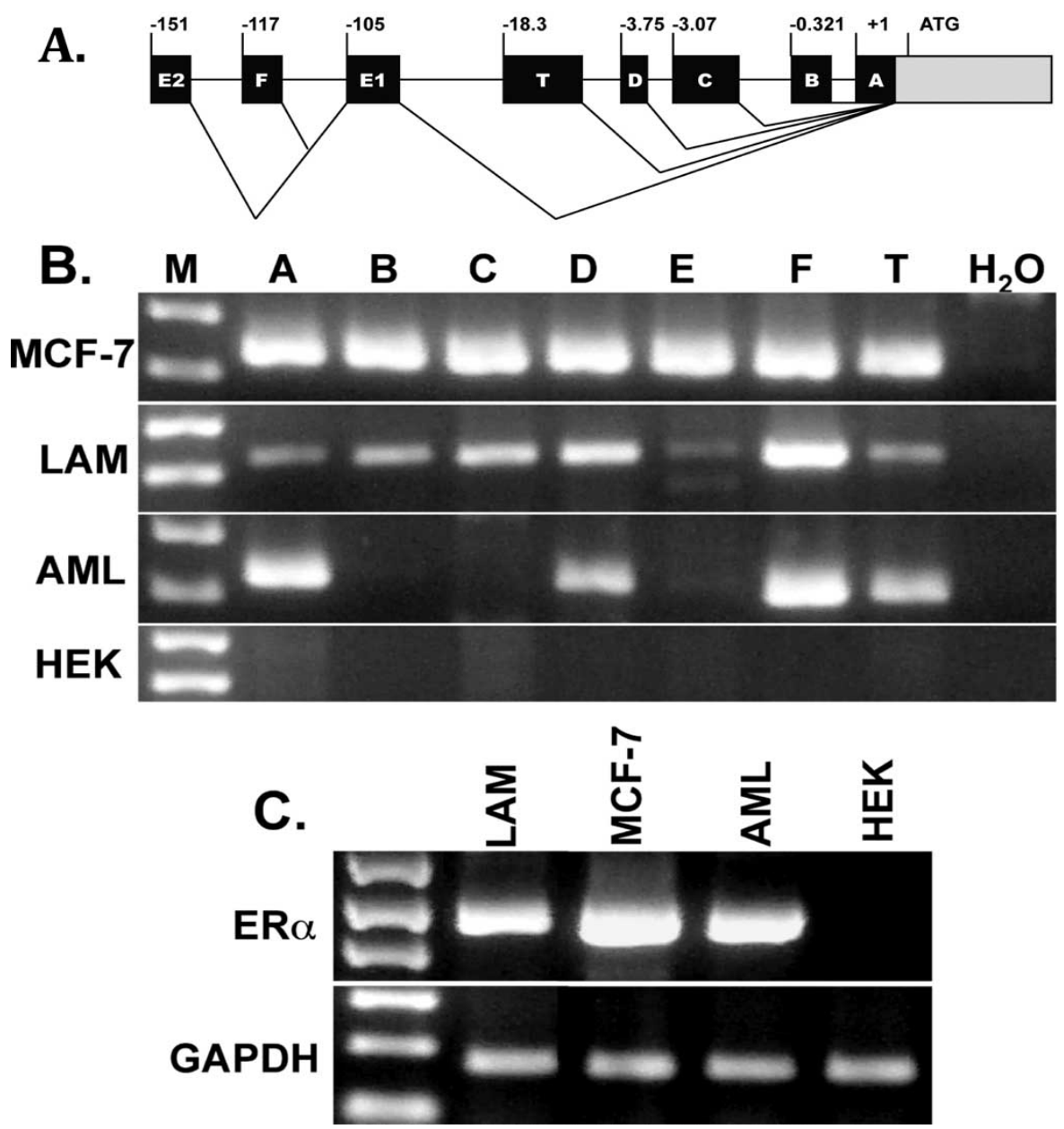

Fig. (1). Cells derived from a LAM lesion utilize promoters A, B, C and F of the ER $\alpha$ gene to express ER $\alpha$ mRNA. (A) A schematic diagram of the ER $\alpha$ gene and the different promoters identified to regulate it as previously described [45]. (B) A series of nested PCR primers as described in the Methods section were used to qualitatively evaluate the promoter usage in total RNA samples derived from a MCF-7 cell line, a LAM cell line, an AML cell line and a HEK cell line. PCR products were separated on a $1.5 \%$ agarose gel and visualized by ethidium bromide staining. The marker (M) bands for each gel corresponds to 200 and 300 base pair DNA fragments from a standard $1 \mathrm{~kb}$ ladder sample. (C) As controls for these studies, the RNA samples used in B were also analyzed by PCR technologies for total ER $\alpha$ mRNA expression and GAPDH mRNA expression. 
for these studies, parallel analyses were performed on MCF7 and HEK-293 cell lines respectively. As seen here, primers specific for the ER $\alpha-A, B, C, D, E, F$ and T were amplified in the LAM cell line, while the analysis of the AML cell line suggest $E R \alpha$ expression is restricted to the usage of promoters $\mathrm{A}, \mathrm{D}, \mathrm{F}$ and $\mathrm{T}$.

\section{LAM Cell Lines and LAM Tissues Appear Demethylated in their Proximal ER $\alpha$-A Promoter}

Global demethylation has been reported for a variety of cancers and this event has been shown to activate previously silenced genes $[51,52]$. To investigate this possibility for the $\mathrm{ER} \alpha$ promoter in LAM disease, a human airway smooth muscle (HASM) cell line, a LAM cell line, an LAMassociated angiomyolipoma (AML) cell line, tissue specimen derived from 5 LAM lesions (accessed through the NIH LAM repository of archived tissues) and 2 tissue specimen derived from normal female lung tissue, were examined with respect to the methylation status of their ER $\alpha-A$ promoter (Fig. 2). This promoter region spans $233 \mathrm{bp}$ upstream of the ATG start site and encompasses $70 \mathrm{bp}$ of the first common exon (a region shared by all ER $\alpha$ promoters). As seen in Fig. (2A), the full-length promoter contains $26 \mathrm{CpGs,} \mathrm{a} \mathrm{number}$ of which have previously been shown to be susceptible to methylation $[53,54]$. The proximal $70 \mathrm{bp}$ sequence of this promoter incorporates 7 of these 26 CpGs. Genomic DNA was isolated from cells and tissues, and unmethylated cytidine residues were converted to uradine residues (thymidine in the PCR amplified DNA) using a commercially available sodium bisulfite kit. The treated DNA was subsequently sequenced using standard PCRbased cycle sequencing technologies and analyzed by autoradiography for $\mathrm{CpG}$ conversion to $\mathrm{TpG}$, or resistance to this conversion due to methylation. Fig. (2B) maps the results of these analyses for the entire promoter A region for HASM and LAM cells, and the proximal $70 \mathrm{bp}$ region of promoter A for the AML cell line, the 5 LAM tissue specimen and the 2 normal lung tissue specimens. Clearly distinguishable differences in methylation status were identifiable when comparing LAM, HASM and AML cell lines. Unfortunately LAM tissue specimen are by nature heterogenous and were therefore much more subtle with

A.

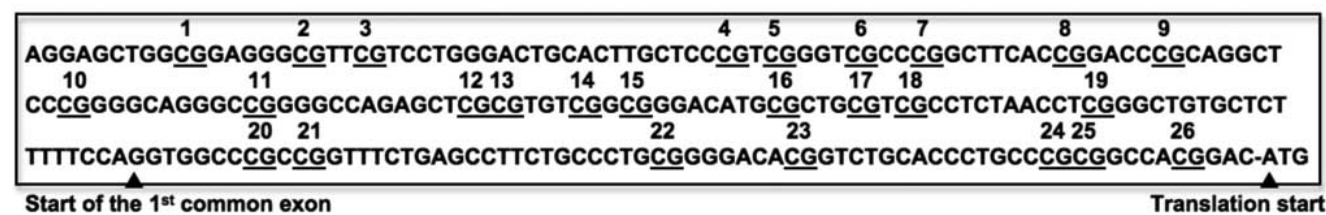

B.

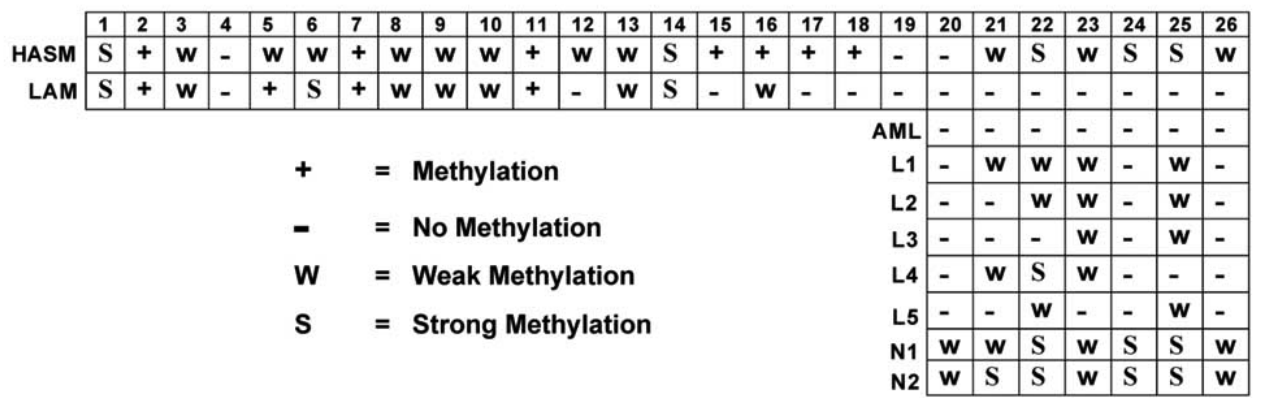

C.

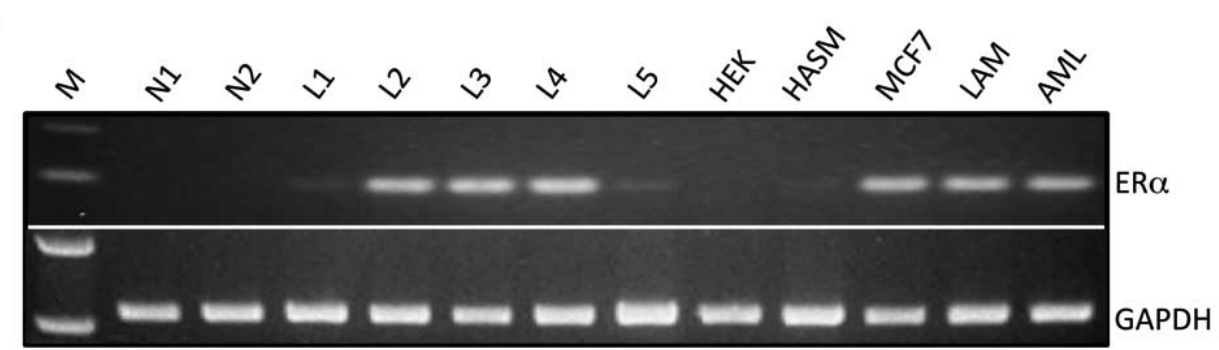

Fig. (2). The $E R \alpha$-A promoter is selectively demethylated in cells derived from LAM lesions. (A) The ER $\alpha$ promoter sequence (+1 to +233: [45]) analyzed in this study is presented, and the 26 methylatable CpG structures are underlined. The first arrowhead identifies the AG residue corresponding to the $1^{\text {st }}$ exon splice site at which all ER $\alpha$ promoter sequences are spliced, and the second arrow identifies the ATG translation initiation site. (B) A table of the results from sequence analysis comparing CpG methylation in LAM cells and HASM cells for the $26 \mathrm{CpG}$ motifs found in ER $\alpha$ promoter-A, and a similar analysis comparing methylation of the ER $\alpha$ promoter-A distal $7 \mathrm{CpG}$ motifs in a LAM-associated angiomyolipoma cell line (AML), 5 LAM tissue samples (L1-L5) and 2 normal lung specimen (N1-N2). See the Methods section for further elaboration of the +/-, weak and strong designations. (C) Agarose gel profile of RT-PCR characterization of ER $\alpha$ and GAPDH mRNA expression in the various cell lines and tissues examined in these studies. $(\mathrm{M}=\mathrm{DNA}$ ladder markers). 
regard to their global differences in methylation status at the seven $\mathrm{CpG}$ sites analyzed. In spite of this limitation it was clear that at least for the limited number of LAM tissues analyzed, methylation differences were present, and that LAM cells and tissue specimens are or become hypomethylated in the distal region of their ER $\alpha-A$ promoter. To provide support for the transcriptional upregulation of ER $\alpha$ in these various tissues and cell lines, we isolated total RNA and performed RT-PCR analyses on them (Fig. 2C). As seen here, all lung tissue samples, to varying degrees, expressed levels of ER $\alpha$ mRNA greater than that observed for the normal lung tissues.

\section{Trans-Regulation at ER $\alpha$ Promoters is Altered in LAM Cells}

It is logical to assume that cis modifications to a promoter result in altered trans-acting factors associating with that promoter. Whether the trans factors are causing the cis modifications or vice versa is unestablished, but trans factors ultimately define the amount and rate of transcription. In an initial look at trans-regulation of the ER $\alpha$ promoter in LAM cells, we analyzed the ER $\alpha$ promoter A region for the binding of two proteins, methyl-CpG binding protein-2 (MeCP2) and histone deacetylase-1 (HDAC1), previously observed to bind to and transcriptionally repress ER $\alpha$ promoters [55-57]. Utilizing chromatin immunoprecipitation technology, formaldehyde-crosslinked chromatin from LAM and HASM cells was selectively immunoprecipitated using MeCP2 (Fig. 3A) and HDAC-1 (Fig. 3B) antisera. Crosslinking was reversed, DNA was isolated and ER $\alpha$ promoter-A DNA was identified by PCR. As seen here, noticeably more $\mathrm{MeCP} 2$ and HDAC-1 were bound to promoter-A in HASM cells than in LAM cells, and binding of MeCp2 in HASM cells could be inhibited if these cells were preincubated with the methylation inhibitor 5-azadeoxycytidine.

In an extension of the above studies we investigated the impact chemical alteration of global DNA methylation and deacetylation had on ER $\alpha$ mRNA expression in LAM and HASM cells. LAM and HASM cells were incubated for 96
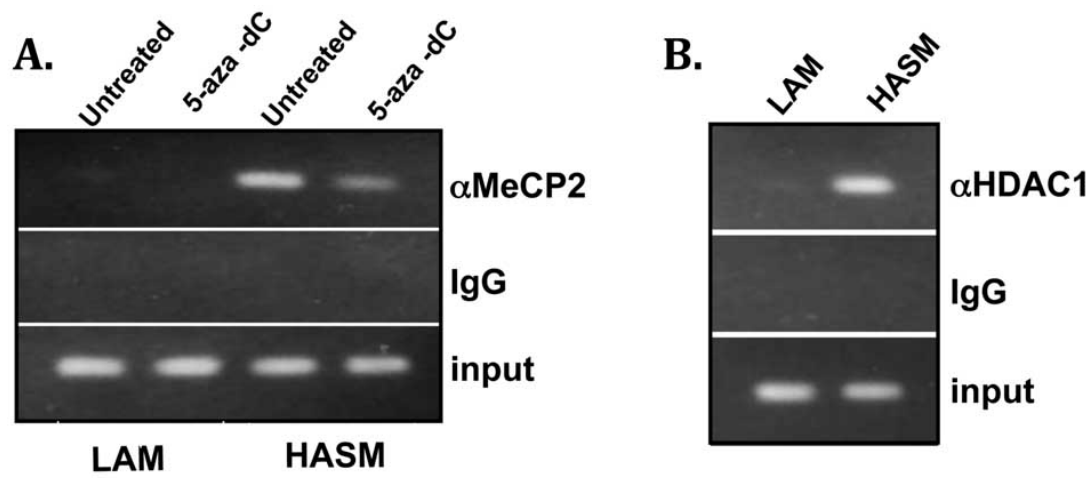

C.

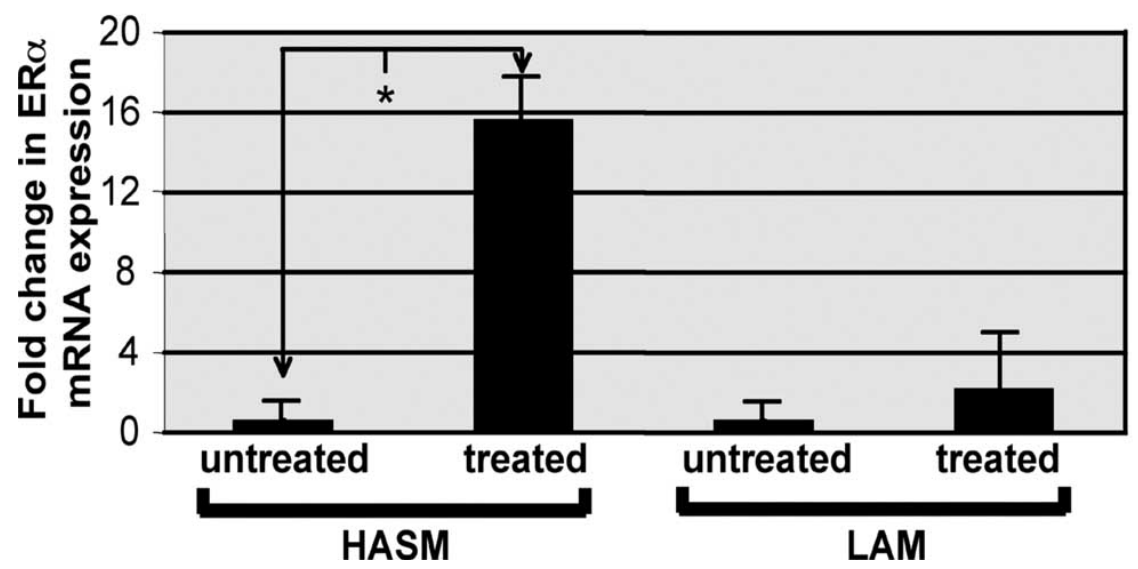

Fig. (3). Alterations in trans-acting factor binding at the ER $\alpha$-A promoter in LAM cells correlate with ER $\alpha$ mRNA expression. (A) Chromatin Immunoprecipitation analyses identify selective binding of methyl-CpG-2 binding protein and HDAC-1 to the ER $\alpha$ promoter-A region in HASM cells. DNA-protein complexes from formaldehyde-fixed LAM and HASM cell lysates were immunoprecipitated using antisera to either methyl-CpG binding protein-2 (MeCP2) or HDAC-1. DNA was extracted from these immunoprecipitates and PCR analyses were performed using ER $\alpha$-promoter-A specific primers. PCR products were analyzed on $1.5 \%$ agarose gels via ethidium bromide staining. These results are representative of this experiment performed minimally 3 times. (B) LAM and HASM cells were incubated for 96 hours in the presence of the demethylating agent $2 \mathrm{uM} 5$-aza and the final 24 hours in the presence of the HDAC inhibitor 5mM 4-PBA. (C) RNA was isolated and analyzed for the expression of ER $\alpha$ mRNA using SYBR green Real-Time PCR technologies. Results are presented as the fold change observed for RNA analyzed from untreated cells. Statistical bars represent \pm SEM for 3 independent experiments. Asterisk indicates statistically significant differences $(p \leq 0.05)$. 
hours in the presence of the methylation inhibitor 5-azadC and the final 24 hours in the presence of the HDAC inhibitor 4-PBA. RNA was isolated and analyzed for the presence of ER $\alpha$ mRNA using SYBR green Real-Time PCR technologies (Fig. 3C). As seen here, inhibition of DNA methylation and histone acetylation results in a substantial increase in ER $\alpha$ mRNA levels in HASM cells, but only a minor increase in LAM cells.

\section{DISCUSSION}

The gender specificity of LAM and direct correlations with mutations in the TSC2 gene, support the hypothesis that disruption of normal TSC2 function can sensitize lung smooth muscle and kidney cells to the mitogenic activity of circulating estrogens. Consistent with this hypothesis is the observation that LAM lesions also display an anomalous expression of $E R \alpha$, suggesting a correlative hypothesis that mutations in the TSC2 gene upregulates the expression of $E R \alpha$. The mechanism for this upregulation is unknown but could be through upregulation of transcription of the ER $\alpha$ gene, upregulation of translation of the ER $\alpha$ mRNA, tissuespecific inhibition of $\mathrm{ER} \alpha$ protein degradation or any combination of these. In this study we investigate the potential for upregulation of $\mathrm{ER} \alpha$ expression through epigenetic changes at the $\mathrm{ER} \alpha$ gene promoter that might facilitate upregulation of the expression of ER $\alpha$ mRNA in LAM. Unfortunately, the human ER $\alpha$ promoter is not a simple promoter to work with in that it has been shown to extend greater than $150 \mathrm{~kb}$ upstream of the 1st coding exon [45]. As many as 7 different ER $\alpha$ promoters have been identified and in several instances selective promoter usage has been correlated with carcinogenesis $[46,58]$. In the LAM-associated cell lines examined in these studies it was observed that transcription expression of the ER $\alpha$ gene was actively being initiated from multiple $\mathrm{ER} \alpha$ promoters. Although these studies were limited to looking at steadystate levels of ER $\alpha$ mRNA and therefore do not directly address transcription rates, our previously published studies demonstrating tuberin's ability to localize to the nucleus [ $[40$, 42] and tuberin's ability to directly impact transcription regulation $[30,41]$ would support a direct impact on ER $\alpha$ mRNA transcription as opposed to ER $\alpha$ mRNA degradation.

The most obvious mechanisms for altered transcription of the ER $\alpha$ gene in LAM would be through some alteration in cis-acting elements at the ER $\alpha$ promoter, alteration in transfactor binding at the $E R \alpha$ promoter or a combination of both. Epigenetic changes at the human ER $\alpha$ gene promoter have been reported for a variety of cancers $[53,54]$. In this study we looked at altered methylation of the $\mathrm{CpG}$ residues in the proximal (A) promoter of the ER $\alpha$ gene. A substantial amount of demethylation was observed to occur in both a LAM lesion-derived cell line and LAM tissue specimen. It was further observed that the alteration in methylation in the LAM cell line was accompanied by a reduced binding of the transcriptional repressors $\mathrm{MeCpG} 2$ and $\mathrm{HDAC} 1$ at the $\mathrm{ER} \alpha$ promoter. These observations have been made for ER $\alpha$ [59] as well as other nuclear receptor gene promoters in which epigenetic changes have been linked to alterations in expression of those genes $[60,61]$, and would suggest that in LAM lesions there is a demethylation at the ER $\alpha$ gene promoter resulting in upregulation of transcription of the ER $\alpha$ mRNA. Further studies are required to conclusively establish whether this is directly caused by mutations in the TSC2 gene and disruption of tuberin/hamartin signaling, or a downstream consequence of tumor formation.

Although the above data support a potential role for epigenetic changes at the ER $\alpha$ promoter in the pathology of LAM disease, a variety of previously published data suggest the mechanism is not as simple as this. These include studies from our laboratory and others that demonstrate: a) tuberin can impact ER $\alpha$ non-genomic signaling through its ability to modulate PDGF signaling [39, 62], p90RSK/ERK signaling and RHEB/mTOR signaling [42, 63]; b) tuberin can inhibit $\mathrm{ER} \alpha$ genomic signaling through its ability to directly bind $\mathrm{ER} \alpha$, directly bind ER $\alpha$ 's coregulatory protein calmodulin and to block ER $\alpha$ DNA binding [41, 42]; c) a study that demonstrates estrogen can promote the survival and pulmonary metastasis of tuberin-null cells [64]; d) a study that demonstrates nongenomic estrogen activities can regulate tuberin stability [65]; and e) a study that provides evidence for upregulation of $E R \alpha$ protein expression in LAM lesions through a post-transcriptional-protein degradation mechanism [66]. Although some of these findings might appear to be somewhat contradictory, they most probably reflect the dedifferentiated state and complexities of LAM lesions. Whether any of these, or some alternative mechanism (e.g. regulation of $\mathrm{ER} \alpha$ mRNA translation), is the driving force of (rather than a consequence of) LAM pathology will require further studies.

\section{CONCLUSION}

In summary, data in this manuscript, for the first time, identify changes in methylation at the $E R \alpha$ promoter associated with the pathogenesis of LAM. These epigenetic changes were further observed to correlate with the expression of ER $\alpha$ in LAM cells and tissues, and correlate with the binding of transcription regulators at the ER $\alpha$ promoter.

\section{ACKNOWLEDGEMENTS}

The authors would like to acknowledge the neighboring laboratories in our department, most especially those of Dr. Kevin Sarge and Dr. Sabire Ozcan, who contributed reagents and equipment, without which these studies could not have been performed. This work was made possible by a grant from the LAM Foundation (LAM052) to DJN. The authors declare that there is no conflict of interest that would prejudice the results of these studies.

\section{REFERENCES}

[1] Chorianopoulos D, Stratakos G. Lymphangioleiomyomatosis and tuberous sclerosis complex. Lung 2008; 186: 197-207.

[2] Hohman DW, Noghrehkar D, Ratnayake S. Lymphangioleiomyomatosis: a review. Eur J Intern Med 2008; 19: 319-24.

[3] McCormack FX. Lymphangioleiomyomatosis. Med Gen Med 2006; 8: 15-23

[4] Finlay G. The LAM cell: what is it, where does it come from, and why does it grow? Am J Physiol Lung Cell Mol Physiol 2004; 286 : L690-3.

[5] Krymskaya VP. Smooth muscle-like cells in pulmonary lymphangioleiomyomatosis. Proc Am Thorac Soc 2008; 5: 119-26.

[6] Ferrans VJ, Yu ZX, Nelson WK, et al. Lymphangioleiomyomatosis (LAM): a review of clinical and morphological features. J Nippon Med Sch 2000; 67: 311-29.

[7] Matsui K, Tatsuguchi A, Valencia J, et al. Extrapulmonary lymphangioleiomyomatosis (LAM): clinicopathologic features in 22 cases. Hum Pathol 2000; 31: 1242-8. 
[8] El-Hashemite N, Walker V, Kwiatkowski DJ. Estrogen enhances whereas tamoxifen retards development of Tsc mouse liver hemangioma: a tumor related to renalangiomyolipoma and pulmonary lymphangioleiomyomatosis. Cancer Res 2005; 65: 2474-81.

[9] Matsui K, Takeda K, Yu ZX, et al. Downregulation of estrogen and progesterone receptors in the abnormal smooth muscle cells in pulmonary lymphangioleiomyomatosis following therapy. An immunohistochemical study. Am J Respir Crit Care Med 2000; 161: 1002-9.

[10] $\mathrm{Yu}$ J, Astrinidis A, Howard S, et al. Estradiol and tamoxifen stimulate LAMassociated angiomyolipoma cell growth and activate both genomic and nongenomic signaling pathways. Am J Physiol Lung Cell Mol Physiol 2004; 286: L694-700.

[11] Smolarek TA, Wessner LL, McCormack FX, et al, Evidence that lymphangiomyomatosis is caused by TSC2 mutations: chromosome $16 \mathrm{p} 13$ loss of heterozygosity in angiomyolipomas and lymph nodes from women with lymphangiomyomatosis. Am J Hum Genet 1998; 62: 810-5

[12] Strizheva GD, Carsillo T, Kruger WD, et al. The spectrum of mutations in TSC1 and TSC2 in women with tuberous sclerosis and lymphangiomyomatosis. Am J Respir Crit Care Med 2001; 163: 253-8.

[13] Borovansky JA, Labonte HR, Boroff ES, Ruddy BE, Mayer AP. Lymphangioleiomyomatosis: a case report. J Womens Health (Larchmt) 2009; 18: 535-8.

[14] Campos FJ, Otero AE, Palacios BA, et al. Lymphangioleiomyomatosis in a postmenopausal woman under estrogen therapy. Med Clin (Barc) 2005; 124: 319.

[15] Kebria M, Black D, Borelli C, et al. Primary retroperitoneal lymphangioleiomyomatosis in a postmenopausal woman: a case report and review of the literature. Int J Gynecol Cancer 2007; 17: 528-32.

[16] Khalife WI, Mahmoud F, Larson E, et al. Pulmonary lymphangioleiomyomatosis in a postmenopausal woman: case report with review of literature. SD J Med 2005; 58:139-43.

[17] Matsushima $\mathrm{H}$, Takayanagi N, Kawata I, et al. [A case of pulmonary lymphangioleiomyomatosis in an elderly woman]. Nihon Kokyuki Gakkai Zasshi 2001; 39: 519-23.

[18] Sandrini A, Krishnan A, Yates DH. S-LAM in a man: the first case report. Am J Respir Crit Care Med 2008; 177: 356.

[19] Logan RF, Fawcett IW. Oophorectomy for pulmonary lymphangioleiomyomatosis: a case report. Br J Dis Chest 1985; 79: 98-100.

[20] Aldeyturriaga JF, Gomez AG, Rodriguez EP. Lymphangioleiomyomatosis: the effectiveness of radiotherapy-induced ovarian function annulment. Respiration 1991; 58:214-8.

[21] Taylor JR, Ryu J, Colby TV, et al. Lymphangioleiomyomatosis: clinical course in 32 patients. N Engl J Med 1990; 323: 1254-60.

[22] Gomez MR. Tuberous sclerosis. $2^{\text {nd }}$ ed. Gomez MR, Ed. New York: Raven Press 1988.

[23] Povey S, Burley MW, Attwood J, et al. Two loci for tuberous sclerosis: one on 9q34 and one on 16p13. Ann Hum Genet 1994; 58: 107-27.

[24] Consortium TT. Identification of the tuberous sclerosis gene TSC1 on chromosome 9q34. Science 1997; 277: 805-8.

[25] Consortium ETS. Identification and characterization of the tuberous sclerosis gene on chromosome 16. Cell 1993; 75: 130515.

[26] Krymskaya VP. Tumour suppressors hamartin and tuberin: intracellular signalling. Cell Signal 2003; 15: 729-39.

[27] Kwiatkowski DJ. Tuberous sclerosis: from tubers to mTOR. Ann Hum Genet 2003; 67:87-96.

[28] Murthy V, Haddad LA, Smith N, et al. Similarities and differences in the subcellular localization of hamartin and tuberin in the kidney. Am J Physiol Renal Physiol 2000; 278: F737-46.

[29] Wei J, Li P, Chiriboga L, et al. Tuberous sclerosis in a 19-week fetus: immunohistochemical and molecular study of hamartin and tuberin. Pediatr Dev Pathol 2002; 5: 448-64.

[30] Henry KW, Yuan X, Koszewski NJ, et al. Tuberous Sclerosis gene 2 product modulates transcription mediated by steroid hormone receptor family members. J Biol Chem 1998; 273: 20535-9.

[31] Goncharova E, Goncharov D, Noonan D, et al. TSC2 modulates actin cytoskeleton and focal adhesion through TSC1-binding domain and the Rac1 GTPase. J Cell Biol 2004; 167: 1171-82.

[32] Goncharova EA, Goncharov DA, Lim PN, et al. Modulation of cell migration and invasiveness by tumor suppressor TSC2 in lymphangioleiomyomatosis. Am J Respir Cell Mol Biol 2006; 34: 473-80.

[33] Lamb RF, Roy C, Diefenbach TJ, et al. The TSC1 tumour suppressor hamartin regulates cell adhesion through ERM proteins and the GTPase Rho. Nat Cell Biol 2000; 2: 281-7.

[34] Astrinidis A, Senapedis W, Henske EP, et al. The tuberous sclerosis complex 1 gene product, interacts with polo-like kinase 1 in a phosphorylation-dependent manner. Hum Mol Genet 2006; 15: 287-97.

[35] Inoki K, Zhu T, Guan KL. TSC2 mediates cellular energy response to control cell growth and survival. Cell 2003; 115: 577-90.

[36] Marygold SJ, Leevers SJ. Growth signaling: TSC takes its place. Curr Biol 2002; 12: R785-7.

[37] Gao X, Pan D. TSC1 and TSC2 tumor suppressors antagonize insulin signaling in cell growth. Genes Dev 2001; 15: 1383-92.

[38] Benvenuto G, Li S, Brown SJ, et al. The tuberous sclerosis-1 (TSC1) gene product hamartin suppresses cell growth and augments the expression of the TSC2 product tuberin by inhibiting its ubiquitination. Oncogene 2000; 19: 6306-16.

[39] Finlay GA, York B, Karas RH, et al. Estrogeninduced smooth muscle cell growth is regulated by tuberin and associated with altered activation of platelet-derived growth factor receptor-beta and ERK-1/2. J Biol Chem 2004; 279: 23114-22.

[40] Lou D, Griffith N, Noonan DJ. The tuberous sclerosis 2 gene product can localize to nuclei in a phosphorylation-dependent manner. Mol Cell Biol Res Commun 2001; 4: 374-80.

[41] Noonan DJ, Lou D, Griffith N, et al. A calmodulin binding site in the tuberous sclerosis 2 gene product is essential for regulation of transcription events and is altered by mutations linked to tuberous sclerosis and lymphangioleiomyomatosis. Arch Biochem Biophys 2002; 398: 132-40

[42] York B, Lou D, Noonan DJ. Tuberin's nuclear localization can be regulated by phosphorylation of its carboxyl terminus. Mol Cancer Res 2006; 4: 885-97.

[43] Goncharova EA, Goncharov DA, Eszterhas A, et al. Tuberin regulates p70 S6 kinase activation and ribosomal protein S6 phosphorylation. A role for the TSC2 tumor suppressor gene in pulmonary lymphangioleiomyomatosis (LAM). J Biol Chem 2002; 277: 30958-67.

[44] $\mathrm{Yu}$ J, Astrinidis A, Howard S, et al. Estradiol and tamoxifen stimulate lymphangiomyomatosis-associated angiomyolipoma cell growth and activate both genomic and non-genomic signaling pathways. Am J Physiol Lung Cell Mol Physiol 2004; 286(4): L690-3.

[45] Kos M, Reid G, Denger S, et al. Minireview: genomic organization of the human ERalpha gene promoter region. Mol Endocrinol 2001; 15: 2057-63.

[46] Flouriot G, Griffin C, Kenealy M, et al. Differentially expressed messenger RNA isoforms of the human estrogen receptor-alpha gene are generated by alternative splicing and promoter usage. Mol Endocrinol 1998; 12: 1939-54

[47] York B, Lou D, Panettieri RA, et al. Cross-talk between tuberin, calmodulin, and estrogen signaling pathways. FASEB J 2005; 19: 1202-4.

[48] Weinmann AS, Farnham PJ. Identification of unknown target genes of human transcription factors using chromatin immunoprecipitation. Methods 2002; 26: 37-47.

[49] Chiurazzi P, Pomponi MG, Pietrobono R, et al. Synergistic effect of histone hyperacetylation and DNA demethylation in the reactivation of the FMR1 gene. Hum Mol Genet 1999; 8: 2317-23.

[50] Liu ZJ, Maekawa M, Horii T, et al. The multiple promoter methylation profile of PR gene and ERalpha gene in tumor cell lines. Life Sci 2003; 73: 1963-72.

[51] Woodson K, Mason J, Choi SW, et al. Hypomethylation of p53 in peripheral blood DNA is associated with the development of lung cancer. Cancer Epidemiol Biomarkers Prev 2001; 10: 69-74.

[52] Widschwendter M, Jiang G, Woods C, et al. DNA hypomethylation and ovarian cancer biology. Cancer Res 2004; 64: 4472-80.

[53] Inoue A, Hayashi S, Aoyagi K, et al. A reporter gene assay for evaluation of tissue-specific responses to estrogens based on the differential use of promoters $\mathrm{A}$ to $\mathrm{F}$ of the human estrogen receptor alpha gene. J Pharmacol Toxicol Methods 2002; 47: 129-35.

[54] Lapidus RG, Nass SJ, Butash KA, et al. Mapping of ER gene CpG island methylation-specific polymerase chain reaction. Cancer Res 1998; 58: 2515-9. 
[55] Muller HM, Fiegl H, Goebel G, et al. MeCP2 and MBD2 expression in human neoplastic and non-neoplastic breast tissue and its association with oestrogen receptor status. $\mathrm{Br} \mathrm{J}$ Cancer 2003; 89: 1934-9.

[56] Sharma D, Blum J, Yang X, et al. Release of methyl CpG binding proteins and histone deacetylase 1 from the Estrogen receptor alpha (ER)30 promoter upon reactivation in ER-negative human breast cancer cells. Mol Endocrinol 2005; 19: 1740-51.

[57] Yang X, Phillips DL, Ferguson AT, et al. Synergistic activation of functional estrogen receptor (ER)-alpha by DNA methyltransferase and histone deacetylase inhibition in human ER-alpha-negative breast cancer cells. Cancer Res 2001; 61: 7025-9.

[58] Lambertini E, Penolazzi L, Giordano S, et al. Expression of the human oestrogen receptor-alpha gene is regulated by promoter $\mathrm{F}$ in MG-63 osteoblastic cells. Biochem J 2003; 372: 831-9.

[59] Leader JE, Wang C, Popov VM, et al. Epigenetics and the estrogen receptor. Ann N Y Acad Sci 2006; 1089: 73-87.

[60] Berger J, Daxenbichler G. DNA methylation of nuclear receptor genes--possible role in malignancy. J Steroid Biochem Mol Biol 2002; 80: 1-11.
[61] Leader JE, Wang C, Fu M, et al. Epigenetic regulation of nuclear steroid receptors. Biochem Pharmacol 2006; 72: 1589-96.

[62] Finlay GA, Hunter DS, Walker CL, et al. Regulation of PDGF production and ERK activation by estrogen is associated with TSC2 gene expression. Am J Physiol Cell Physiol 2003; 285: C409-18.

[63] Yu J, Henske EP. Estrogen-induced activation of mammalian target of rapamycin is mediated via tuberin and the small GTPase Ras homologue enriched in brain. Cancer Res 2006; 66: 9461-6.

[64] Yu JJ, Robb VA, Morrison TA, et al. Estrogen promotes the survival and pulmonary metastasis of tuberin-null cells. Proc Natl Acad Sci USA 2009; 106(8): 2635-40.

[65] Flores-Delgado G, Anderson KD, Warburton D. Nongenomic estrogen action regulates tyrosine phosphatase activity and tuberin stability. Mol Cell Endocrinol 2003; 199: 143-51.

[66] Glassberg MK, Elliot SJ, Fritz J, et al. Activation of the estrogen receptor contributes to the progression of pulmonary lymphangioleiomyomatosis via matrix metalloproteinase-induced cell invasiveness. J Clin Endocrinol Metab 2008; 93: 1625-33.

(C) Noonan and Lou; Licensee Bentham Open.

This is an open access article licensed under the terms of the Creative Commons Attribution Non-Commercial License (http:/creativecommons.org/licenses/by-nc/ $3.0 /$ ) which permits unrestricted, non-commercial use, distribution and reproduction in any medium, provided the work is properly cited. 